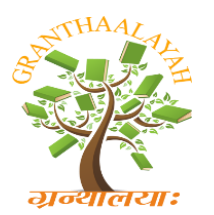

INTERNATIONAL JOURNAL OF RESEARCH GRANTHAALAYAH

A knowledge Repository

Social

\title{
BEFORE LATE: LET'S ACCOMPLISH THE GREAT- AN ARGUMENT TO SAVE ENVIRONMENT WITH SPECIAL REFERENCE TO CONDITION OF NEPAL
}

\author{
Dahal, Atindra ${ }^{* 1}$ \\ ${ }^{* 1}$ Kathmandu School of Law, Dadhikot Bhaktapur, NEPAL
}

\begin{abstract}
Development and civilization have been top-rated priorities and indication of human success in the world; and the largest segment of world talent are immersing to mark new and ever unexperimented record in this course. But paying more attention towards money centric gain and material prosperity centric civilization, an irrational attack on environment is rife everywhere. In last few decades, the environmental strength of world has been largely damaged and it has offered severe impacts on human health now. Though, people were more over-swayed with anthropomorphic use of environment and some transitory progress gained, slowly the imbalance of environment and its reverse effects on human lives have started taking limelight of people. And now, environment seems to be equally pressing and compelling agendas of human checklist to do. If not initiated anything great, it may be more than late to save us and future generation. Thus, the article tries to disclose the impacts of environmental degradation and urges to have efficient actions to alleviate the situation with acknowledging and accessing few of initiatives taken, here so forth.
\end{abstract}

Keywords:

Environment; Environmental Damage, Human Health, Nature, Conservation, Promotion.

Cite This Article: Dahal, Atindra, "BEFORE LATE: LET'S ACCOMPLISH THE GREATAN ARGUMENT TO SAVE ENVIRONMENT WITH SPECIAL REFERENCE TO CONDITION OF NEPAL" International Journal of Research - Granthaalayah, Vol. 4, No. 4 (2016): 13-19.

\section{INTRODUCTION}

Environment is one of key natural elements and gifts for human beings as people live only on the great help of environment. Sans such precious bequest, the human existence is nether imaginable nor is it possible. Nonetheless, being thoroughly slipshod and reckless about gravity of the issues, for long, people were simply using it and damaging too deeming as if nature is granted for arbitrary and wanton use for human eccentricity and intellectual subsistence. Neither they thought of values of environment nor did they imagine about the disastrous risk of exhausting it in this manner. Thus we are having many of natural and ecological traumas which are caused on 
the ground of reckless impedance and over encroachment on the environment. Despite growing slipshod and slapdash for long term, these days, people have been quite conscious of environment as they are frequently hit with such natural pitfalls and calamities.

Since last many years, we have been coming with rapid deterioration on quality and strength of environment. In the regard, Environmental Statistics Nepal too draws light on comparative data to present the degrading status of our environmental health and argues, "It has become essential to incorporate those policies followed and continued in the development plans and programs realizing the problems of climate change and environmental degradation" ( 2013: Page No, 16). The report makes striking necessities on every policy and plan being sufficiently careful about status of environmental upgrading. Shrestha writing "the magnitude of the problem is very high in a mountainous and developing country like Nepal" (1994: 137) makes due stress over the issues and feels that environmental degradation is rapidly taking places. Eckholm's assertion "Nepal's ecological situation has become worse and the country is further approaching towards the brink of ecological collapse. In probably, no other mountain countries are the forces of ecological degradation building so rapidly and visible" (1976: 76) also supports Shrestha's version. Another remark, "In a flash within the decade ending in 1971, Nepal lost 50\% of its forest cover" (Moddie, 1981: 344) makes a powerful hint that Nepal is experiencing radical and rapid degradation of environment. "Nepal has been reduced to four million hectors or about $27 \%$ of the total land area of Nepal" (the Rising Nepal: 1992) justifies that even government has assimilated the galloping overnight destruction and damage of resources and environmental strength of Nepal.

In regard to such rapid damage to environmental health and strength, series of the fatal problems are created and those have often left entire society of humans helpless to some extent. Thus, Nissani has regarded it as the one of two long term problems. The long terms might be as it is caused in long term and will effect till long terms. Those two problems are 'too many people and too few trees'. To make stress over the problems caused in reference to destruction of environment, he adds, "the chances of contracting cancer, emphysema or asthma are far higher now than they were centuries ago [...] Soil erosion, desertification, and deforestation are proceeding apace" (2010: 30). The savage and preposterous damage of environment on ground of over population has severely crippled the human health and many of other aspects of ecological balance. In sequel, uncountable problems are noticed. Global warming and depletion of ozen layer has caused a lot of weather extremism and oddities. These are all outcome of humans' negligent encroachment over the environment and there may be more lethal and massive pitfalls ahead. As an effect of degradation of environment, Rana writes, "It has been observed that some of the river beds in the Terai are rising from 15 to $30 \mathrm{~cm}$ every year" (1976: 115). Environment destruction induced pollution is a worldwide problem and its adverse effect to influence the health of human populations is great (Fereidoun and et al: 2007). Envisioning such tragedy ahead, Anderson argues as that there has enough information to estimate natural disaster events (1990). And the author rightly unmasks the possibility of unbearable natural mishaps and hazards provided humans don't revisit the monolithic and myopic consumption of environment as done till these days.

Despite surreal depiction and inescapable negotiation with natural mishaps and noticing alarming bells for more outlandish future, still the human consciousness has not grown up into that 
positive volume and pro-active magnitude in which it had to be taken in fact. People throughout the nation use and misuse the environment in different petty excuses as well. The record of Environmental Statistical Survey reads "still 64 percent people use firewood for cooking" (2014: 40) in Nepal. Such uses offer devastating double-fold risk as environment is damaged one way and smoke is produced in the other. Pollution on soil, water and air too comes with the production of smoke and vice versa. Malla and Shrestha as well reconfirm this assumption and write, "Fuel wood in Nepal alone accounts for $95 \%$ of all wood consumption in rural areas and $87 \%$ of all energy consumption of country" (1983: 90). In addition to it, Bajracharya notes another key villain on this issue and jots his idea as, "During the dry season (May to June) burning of forest and grassland is commonly in use" (1983: 237). Thus various reasons are culprit to destruct the environment in Nepal.

Only having undestroyed and sound environment is tool to tackle the problems of pollution. For instance, the Bangladesh Water Development Board (BWDB, 1987) suggests that upstream forestation somehow stops speed and volume of pollution to some extent. Burton and et al advise to have 'preservation and promotion of environment health' (1993) to the expectation of overcoming such contamination.

Depletion of environment has been more rife and aggressive once we initiated development. The more modern and industrialized we are growing, the more naked our lands are being. From vegetations and trees covered human settlement, we are jumping into jungle of concreters. Though we are outwardly pretended of being happy and leading more comfortable life as boon of development, the inverse relationship between development and destruction of environment has caused a severe damage on quality lives of humans. It is now the time the same development has been bane for people. Poet Cowper has ironically marked the situation and has called it a 'perishing pleasure' (2010: 100) of modern people. Because the pleasure we are trying to gain and extend by commanding destruction of environment is sure to wrap us in an escapable and unresolvebale peril in near future, poet has directed that our temporary pleasure of being modern with destruction of environment and extension of urbanization will leave us in severe problem a day and symptoms are already in sight.

Environmental statistical Nepal has a report which shows that 2525640 hector of land turned uncultivable because of flood and landslide in 2011/12 which was mere 225448 hector in 2001/2. Thus it seems that the barrenness of land has increased more than 10 times in the period. The very report depicts the estimated calculation of loss of properties and livestock because of disasters jumped to 3425 million in 2011 from 240 million in 1983 (2014). These figures highlight that we are incurring fairly greater loss and damage because of environmental destruction induced disasters and pitfalls.

Many of natural calamities and unwanted pitfalls are irregularly regular because of our negligence to the environment. Environmental statistics Nepal 2013 depicts the loss of many lives, properties and livestock because of it. Environmental conservation, which could be the one and only solution to tackle the adverse effects and sprees, has been quite quiet in terms of taking some remarkable actions. Carter argues persuasively that to be effective, disaster management should be implemented as a comprehensive and continuous activity, not as a periodic reaction to individual disaster circumstances (1998). The very argument urges for 
integrated and consistent efforts form each and every individual and stakeholders in regard to conservation and promotion of environment.

These all scenes and scenarios justify that we are growing more indifferent and immoral in course of harnessing development and so on. For considerably long period of time, we exploited environment in such myopic and shortsighted way that regular spins of bad luck are wrapping us. But slow and gradual consciousness on behalf of people has caused a lot of contributive functions to work in this favour. In course of saving environment, even government has come with some of the actions for self and incentives for the people. It has been an issue of global concern for people. Out of many agendas to drag limelight of international power blocs, environment has been equally commanding issue as like terrorism, development, disarmament or any other cardinal agenda of political discursively. To lay equal stress on Reiger argues that if the deteriorating situation of the mountain and hill environment is not reversed and better managed, this population growth may lead to the collapse of the delicately balanced ecological system between Himalayas and the Ganges plain (1976).

Saving nature is one of prime jobs people are to do. National and international concern has rightly focused on the issue. To discuss the growing level of the environment consciousness, Bhatt and Khanal write, "One of the tools available to satisfy this need is represented by the procedure of Environmental Impact Assessment (EIA). This procedure involves the systematic identification and evaluation of the impacts on the environment caused by a proposed project" (2009: 160). Very argument unmasks that the government has been quite conscious of not having any destructive and irreparable damage on environment while carrying out any of projects. Every project now has to assure not to have adverse impacts on environmental hygiene. Such compulsion can be one of solid actions taken to safeguarding the environmental health of the nation.

To assure the better dedication in environment conservation, the government of Nepal enunciated environment conservation related policies in the Seventh Plan (1985-90). To assess the root of consciousness in this regard, Shrestha writes, "During the earth summit held at Rio de Janeiro in Brazil in 1992, Nepal expressed her commitment to the conservation of the environment and its resources. The eight plan (1992-1997) adopts some basic polices to restore the deteriorating environment of Nepal" (1994: 144). In reference of international conference on intention of preserving and promoting environment, tacking the climate change problems under control could be easier, the globe has assimilated. In series, the international summits for global warming and climate change are being held, annually. Few initiatives are taken in Nepal as well. Madhav Kumar Nepal held the cabinet's meeting into base camp of Mount Everest. The meeting was a symbolic enough to draw the attention of entire world on disastrously growing adverse and unbearable climate change. In his tenure of prime-ministership, Dr. Baburam Bhattarai came with idea of planting two trees in each house. Entire society of writers has come with notion of composing literatures to assist and aware people in terms of saving environment under banner of green literature or eco-centrism or eco-criticism. Discussing about Green Literature, Bary writes, "they read the major literary works from eco-centric prospective, with particular attention to the promotion of natural world" (2007: 264) and mentions the reading and writing from that particular prospective of saving and making nature is a stronger emergence from recent past when the world started reeling with rapid destruction of nature. Authors and scholars too are 
advising for revision and formulation of policies to save nature and maintain environmental balance. Focusing to follow and implement the wide sense of awareness and advocacy initiated by various groups of people, Alario writes, "The substantive input to the environmental policy deliberation must be closely scrutinized" (1995: 43). Rosenstock, who believes that the significance of environmental factors to the health and well-being of human populations is inexplicable, also notes that the human consciousness for environmental conservation is increasingly apparent (2003).

Many humanitarian organizations throughout the globe too have equally harboured their focus into the environment as it is one of key ingredients and indispensible aspects of sustainable development. Goals devised for any sorts of sustainable development may remain incomplete without due promotion and preservation of environment. For the reason, national and international non-governmental organizations too have been laying attention on the issues. From Sierra Club to Greenpeace, there are many organizations having well repute and recognition in this sector (Web: 1). VIN, known for Volunteers Initiative Nepal, is one in Nepal trying out the hand for the purpose.

From literature to political arena, environment has well drawn the limelight of a great number of people. Thus is can be argued that, conservation of environment is an area worth and must for working for today's humans. Mere working in other issues has caused a severe damage in environment. Almost every activity from publishing the visiting cards to establishing industry, ecological survey and destructions are to be taken into care. Many organizations have started to recognize themselves as eco-friendly zone as well. Goodall, taking about urgency of having ecofriendly human activities from daily living to developmental action plans, argues that the adoption of environmental auditing in any economic sector should be made mandatory (1995).

Thus everyone from individual to institutional level has to bring certain consciousness in saving environment. Developing countries' governments have not been greatly conscious enough to issues of environment into level they should have been as like unemployment, poverty and so on. Political gridlock and logger-heading induced impasse has more and mostly occupied them thus the attention is not well paid towards issues of environment. And Rolston regarding that as severe negligence and more suicidal for future argues, "It would be foolish for all, even for white South Africans acting in their own self-interest, further to jeopardize environmental health, rather than to look first and resolutely to solving their social problems" (1996: 256).

Thus, the global concern has fallen into environmental issue. If we don't initiate any substantial attempt to conserve it for us and for future but still make a wait, healing environment may be too late. Though it had to commence quite early, Khan and Gauri write "still time is left in the hands of global institutions, governments and local bodies to use the advance resources to balance the environment for living and initiates the breathed intellectuals to live friendly with environment" (2011: 276) and make a hint, still chances are high to rebalance humans with environment provided serious efforts are rightly unleashed. Even for development and make it sustainable, conservation and promotion of environment is a must mandatory norms. To make it further clear, Rio Declaration on Environment and Development states, "In order to achieve sustainable development, environmental protection shall constitute an integral part of the development process and can-not be considered in isolation from it". 


\section{CONCLUSION}

The analysis and inference make an urgent urge for everybody else to contribute optimum from their own level to have positive voice and action to save environment; and it is saving us as well. Nothing can shield to save us, if unwonted sprees on environment are not checked and corrected. To take into a point, saving environment is most urgent and incomparably needy step to take grand and great initiative sans any delay and excuse.

\section{REFERENCES}

[1] Alario, M. (1995). Environmental Destruction, Risk Exposure and Social Asymmetry. Lanham, MD: University Press of America.

[2] Anderson, M.B. (1990). Analyzing the Costs and Benefits of Natural Disaster Responses in the Context of Development. Washington: The World Bank.

[3] Bajracharya, Deepak. (1983). "Deforestation in the Food/Fuel Context: A Historical and Political Prospective from Nepal”. Mountain Research and Development, Vol III, No 3, $P+227-240$.

[4] Barry, Peter. (2007). Beginning Theory. UK: Manchester University Press.

[5] Bhatt, Ramesh Prasad \& Khanal, Sanjay Nath. (2009). "Environment Impact Assessment System in Nepal- An Overview of Policy, Legal Instrument and Process”. Kathmandu University Journal of Science Vol. , No. II. Kathmandu: Department of Environmental Science and Engineering, School of Science, Kathmandu University, P+ 160-170.

[6] Burton, I., R. Kates, and G.F. White. (1993). The Environment as Hazard. New York: The Guildford Press, 1993.

[7] Carter, Nick. (1998). Disaster Management: A Disaster Manager's Handbook. Manila, Philippines: Asian Development Bank, 1998.

[8] Cowper, William. (2010). "The Poplar Field”. The Magic of Words. Edited by Shreedhar Prasad Lohoni and Rameshwor Prasad Adhikary. Nepal: MK Publication and Distribution House, 2010.

[9] Eckholm, Eric P. (1976). Losing Ground: Environmental Stress and World Food Prospect. New York: W. W. Norton and Company, 1976.

[10] Environment Statistics of Nepal 2013. (2014). Kathmandu: Government of Nepal, National Planning Commission Secretariat, Central Bureau of Statistics, 2014.

[11] Fereidoun, H., Nourddin, M. S., Rreza, N. A., Mohsen, A., Ahmad, R. \& Pouria, H., (2007). "The Effect of Long-Term Exposure to Particulate Pollution on the Lung Function of Teheranian and Zanjanian Students”. Pakistan Journal of Physiology, 3(2), pp. $1-5$.

[12] Goodall. B. (1995). Environmental Auditing: A Tool for Assessing the Environmental Performance of Tourism Firms. The Geographical Journal, 161(1), pp. 29-37.

[13] Khan, Mashhood Ahmad \& Gauri, Arsalan Mujahid. (2011). Journal of Arts, Science \& Commerce. Researcher's World. E-ISSN 2229-4686/ ISSN 2231-4172. Vol.-II, Issue -2, April, $P+276-286$.

[14] Malla U M and Shrestha C B. (1983). Environment Resource Management in Nepal. Kathmandu: Bhimsen Thapa.

[15] Moddie, A. D. (1981). "Himalayan Environment". The Himalayan Aspects of Change. Edited by Lall \& Moddie. New Delhi: Oxford University Press, P+ 341-350. 
[16] Nissani, Moti. (2010). Two Long Term Problems: Too Many People, Too Few Trees. The Heritage of Words. Edited by Shreedhar Lohoni, Rameshwor Adhikary and Abhi Subedi. Kathamndu: Ekta Books, P+ 29-36.

[17] Rana, Ratna S J B. (1976). "Notes for a Design: Environment and Development Planning”. Mountain Environment and Development. Kathmandu: SATA.

[18] Reiger, H. C. (1976). "Floods and Droughts, the Himalayas and the Ganges Plain as an Ecological System”. Mountian and Environment Development. Kathmandu: SATA.

[19] Rio Declaration on Environment and Development, Principle 4, UNCED document A/CONF. 151/26, vol. I, ps. 15-25.

[20] Rolston, Holmes. (1996). "Hunger and the Environment: Feeding People versus Saving Nature". World Hunger and Morality. Ed. William Aiken and Hugh LaFollette. Englewood Cliffs, NJ: Prentice-Hall, P+ 248 to 258.

[21] Rosenstock, L. (2003). "The Environment as a Cornerstone of Public Health". Environmental Health Perspectives, 111(7), P+376-A377.

[22] Shrestha, Vinod, P. (1994). "Environmental Problems in the Nepal Himalaya" Contributions to Nepalese Studies. Vol 21, No. 2. Nepal: CNAS/TU, P+137-151.

[23] The Rising Nepal. September 2. 1992. Kathmandu.

[24] http://webecoist.momtastic.com/2008/09/24/25-environmental-agencies-andorganizations/ 